\title{
PAF およびその関連物質の生物活性
}

\author{
第 II 編 PAF（血小板活性化因子）の血管透過性立進作用に \\ 及ぼす阻害物質の影響
}

\author{
関西医科大学 第 1 内科学教室（指導：安永幸二郎教授） \\ 関西医科大学 医化学教室（指導：齊藤國彦教授）
}

山本真理子

(平成 3 年10月 24 日受付)

要旨：ラット子宮内のリゾホスファチジルコリン（LPC）とスフィンコミエリン（SPH）にはPAFによるウサギ洗 净血小板の凝集阻害作用が認められているが, 今回 LPC と SPH のラット皮唐に打けるPAF の血管透過性六進作用 に及ぼす影響を調べた。

PAF による血管透過性立進作用は濃度依存的にその程度を増強し, PAF 受容体拮抗剤である CV-3988，L-652, 731 によって有意に抑制された。 5 及び $10 \mu \mathrm{g}$ の $16 ： 0$ LPC はPAF の血管透過性克進作用を有意に抑制したが, $50 \mu \mathrm{g}$ 以上ではかえって LPC 単独でも血管透過性六進作用が認められた。

18：0 LPC, SPHには抑制作用を認めなかった。

16：0 LPC はヒスタミン, ブラジキニン，セロトニンによる血管透過性六進作用を抑制しなかった。

Key words : 索引用語：PAF（血小板活性化因子），ラット子宮, PAF 拮抗剤，血管透過性，ラット皮周

\section{I. 粕豆}

1972年アナフィラキシー反応解析の過程において血小 板を活性化する因子として発見された PAF（血小板活

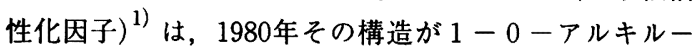
2 -アセチルーsnーグリセロー3ーホスホコリンと決定 され ${ }^{2)}$ エーテル型コリンリン脂質の一分子種であること がわかった。その後 PAF の研究は飛躍的に進展し; 血 小板の活性化 ${ }^{3)}$ の他, 好中球の活性化, 回腸平滑筋の収 縮 $^{5)}$ 血圧の降下作用, 血管透過性の六進, ${ }^{7,8)}$ 等多彩な生 理作用のあることが明らかにされている。

血管透過性の元進作用に関して, Humphrey $ら^{7)} に よ$ れば色素漏出を示標として評価した場合, モルモットで は $0.1 \mathrm{pmol}$, ウサギとラットでは $1.0 \mathrm{pmol}$ でその作用を 最初に誘発し、ヒスタミンに比べ1,000〜10,000倍強力 であると報告している。

PAF は種々の刺激に応じて多くの炎症細胞によって 新しく産生し放出されるものと言われてきた ${ }^{9,10,11,12)}$ が, しかし, 新しく産生されたPAF のほとんどは放出 されずに, 細胞内もしくは細胞表面に留ると言われてい
$3^{13,14,15,16,17,18)}$ 一方, 正常なと卜の唾液, ${ }^{19)}$ 尿, ${ }^{20)}$ 血液 ${ }^{21)}$ からも検出され, さらに何ら外来性の刺激を与えていな い正常ラット子宮 ${ }^{22)}$ やラット胃 ${ }^{23)}$ 及び牛脳 ${ }^{24)}$ に PAF の 活性が証明された。

1987年, 中山らによって正常ラット子宮内には, PAF によるウサギ洗浄血小板の凝集を阻害する脂質性物質が 共存することが見出され，その後それらの阻害物質は 1 ーアシル型及び 1 -アルキル型リゾホスファチジルコリ ンとスフィンゴミエリンであることが報告された。

著者は, これらの阻害物質が, 血小板凝集作用以外の 他の PAF 作用すなわち血管透過性の元進作用には, ど の様な影響を及ほすかについて検討を加えた。

\section{II. 実験材料と方法}

1. 実験材料

a. 阻害物質

(1)リゾホスファチジルコリン (LPC) とその精製 1,2-ジパルミトイルホスファチジルコリン (DPPC) 及び1,2-ジオレオイルホスファチジルコリン（DOPC） (東京医科歯科大学教養部化学教室, 村松敏夫教授より 
御恵与戴いたもの）をアルミナカラムクロマトグラフィ にて精製し，その $1 \mathrm{mg}$ 脂質リン相当をジエチルエーテル $3 \mathrm{~m} \ell に$ 溶解し, これに乾燥重量 $0.76 \mathrm{mg}$ のホスホリパーゼ $\mathrm{A}_{2}$ (Crotalus adamanteus) を溶解し0.22M塩化カルシウ $\triangle 0.1 \mathrm{~m} \ell, 0.02 \mathrm{M}$ 塩化ナトリウ $40.1 \mathrm{~m} \ell$, さらに $0.1 \mathrm{M}$ 卜 リス一塩酸緩衝液（pH7.4） $0.2 \mathrm{~m} \ell$ の混合液を加え一晚 激しく振盪した。年) エーテルを窒素気流下で除去し，そ の後, Bligh-Dyer 法 ${ }^{27)}$ で総脂質を抽出し, $1 \mathrm{~g}$ のケイ

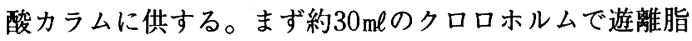

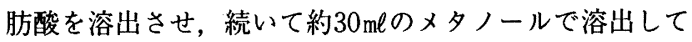
くる LPC 画分を得た。この画分は薄層クロマトグラ フィー（TLC）を用いクロロホルム：メタノール：水 $65: 35: 6 \quad(\mathrm{v} / \mathrm{v} / \mathrm{v})$ の溶媒系にて展開した結果, 単一 であった。更に LPC の構成脂肪酸を同定する為に，ナ スフラスコに $5 \mu \mathrm{g}$ 脂質リン相当の LPCをとり, 完全に 溶媒を除去し， $5 \%$ メタノール性塩酸溶液を $3 \mathrm{~m} \ell$ 加え 1 時間還流し, ヘキサン $5 \mathrm{~m} \ell$ と少量の水を加えよく振盪し ヘキサン相に抽出された脂肪酸メチルエステルを，ガス クロマトグラフにて分析した。用いた器械は Shimadzu GC-8AG ガスクロマトグラフであり，カラムは $10 \% \mathrm{Si}-$ lar 10-C Gaschrome-Q (100/120 -メッシュ $2 \mathrm{~m} \times$ $3 \mathrm{~mm})$ であった。カラムの温度は最初 8 分間 $190^{\circ} \mathrm{C}$, そ の後 $5{ }^{\circ} \mathrm{C} /$ 分の割で $225^{\circ} \mathrm{C}$ まで昇温し以後その温度を維持 した。検出は水素炎イオン化検出器を用いピークエリア は Shimadzu C-RIA クロマットパックコンピューター にて自動計測した。その結果, 検出した脂肪酸は DPPC からはパルミチン酸, DOPC からはオレイン酸のみで あった。

(2)スフィンゴミエリン (SPH)

SPH は牛脳 SPHを使用し Serdary Research Laboratories Cat. No. A-41 から入手した。TLCではクロロ ホルム:メ夕ノール：水 $65: 35: 6(\mathrm{v} / \mathrm{v} / \mathrm{v})$ の溶媒 系にて展開しスポットが単一であることを確認した。

b．その他の化学物質および試薬

18:0 PAF (Bachem. Fein Chemicalien, AG) $100 \mu \mathrm{g} に$ $100 \mu \ell$ のタノールを加え溶解し, 総量が500 ように生理食塩水を加えた。エッペンドルフチューブに て $15 \mu$ 〕ずつ分注し， $-20^{\circ} \mathrm{C}$ 以下にて凍結保存した。ヒ スタミン $5 \mathrm{~g}$ を生理食塩水 $50 \mathrm{~m} \ell に$ 溶解し, 用に望みその

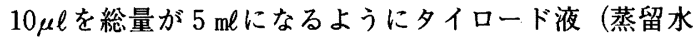
$1 \ell$ 中に, 塩化ナトリウ $48.0 \mathrm{~g}$, 塩化カリウム $0.2 \mathrm{~g}$, 塩 化マグネシウム (六水塩) $0.22 \mathrm{~g}$ ，塩化カルシウム（二 水塩) $0.265 \mathrm{~g}$, リン酸二水素ナトリウム (二水塩) $0.06 \mathrm{~g}$ を順次加え完全に溶解させ $4{ }^{\circ} \mathrm{C}$ に保存したも の）を加えた。セロトニン $100 \mathrm{mg}$ を生理食塩水 $100 \mathrm{~m}$ に溶

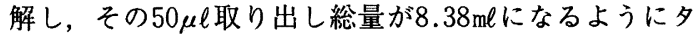
イロード液を加えた。ブラジキニン $1 \mathrm{mg}$ を生理食塩水 $2 \mathrm{~m} \ell$ に溶解し, その $500 \mu \ell$ 取り出し総量が $4167 \mu \ell に な$ るようにタイロード液を加えた。それぞれのアゴニスト と 16：0 LPC $10 \mu \mathrm{g} / 50 \mu \ell$ を混合し，投与の際には， 1 ケ所 $100 \mu \ell の$ 注入となるように調整した。

実験に供する直前までは，LPC，SPH はクロロホルム :メタノール $(1: 1, \mathrm{v} / \mathrm{v})$ に, $\mathrm{CV}-3988$ (RS-2methoxy-3-(octadecyl-carbamoyloxy) propyl 2-(3thiazolio) ethylphosphate, 武田薬品), ヒスタミン, ブ ラジキニン，セロトニンは生理食塩水に， L-652, 731 (trans-2, 5-bis-(3, 4, 5-trimethoxyphenyl) tetrahydrofuran, 日本新薬) はジメチルスルフォキサイドに 溶解しー $20^{\circ} \mathrm{C} に て$ 保存した。

\section{c . 色素液の調製}

ブリリアントブルー 6B（Niagara sky blue 6B, ナカ ライテスク）を $0.43 \%(\mathrm{w} / \mathrm{v})$ 塩化ナトリウム水溶液 に $50 \mathrm{mg} / \mathrm{m} \ell$ となるように混じ，スターラーで約 2 時間摫 拌した。終了後ヒダ折り滤紙 (TOYO filter paper qualitative 直径 $12.5 \mathrm{~cm} \quad 2$ ) で滤過して使用した。

2. 血管透過性の測定方法

血管透過性は血管外に漏出したブリリアントブルー 6 B を大石 ${ }^{28,29)}$ 片山ら ${ }^{30)}$ の方法に従って比色定量した。 具体的には，第 I 編にて述べたとおりである。テスト物 質の調整は全て使用直前に行ない，LPC およびSPH は クロロホルム：メタノール（1：1，v/v）の溶媒を 窒素気流下に除去し, 又凍結保存していた $18 ： 0 \mathrm{PAF}$, CV-3988，L-652, 731, ヒスタミン, ブラジキニン, セロトニンは解凍し $0.1 \%$ BSA 含有タイロード夜を加え た。タイロード液の炭酸水素ナトリウムは使用のつど添 加した。

LPC $10 \mu \mathrm{g} / 50 \mu \ell\left(4 \times 10^{-4} \mathrm{M}\right)$ は上記タイロード液 に溶解せず，均一化する為ブランソンのソニケーターを 用いた。

SPH は上記タイロード液に懸濁したものおよび $0.01 \%$ トライトン X-100含有タイロード液に溶解した ものを用いた。

18：0 PAF の血管透過性光進作用に対する LPC, $\mathrm{SPH}$ 等の抑制効果を調べる際には，18：0 PAF とテス ト物質をそれぞれあらかじめ混合し100 $\mu \ell$ を皮内注射し た。

標準曲線は次のようにして作成した。先に述べたブリ リアントブルー 6 B の塩化ナトリウム溶液を $0,0.1$, $0.2 ， 0.3 ， 0.4 \%$ になる様にタイロード溶液を加え調整 した。共栓付きガラス管 $(10.0 \times 1.5 \mathrm{~cm})$ にそれぞれ 
$100 \mu \ell$ と $1 \mathrm{~N}$ 水酸化カリウム $0.8 \mathrm{~m} \ell, 0.6 \mathrm{~N}$ リン酸溶液 $3 \mathrm{~m} \ell, ア セ ト ン 6.5 \mathrm{~m} \ell$ を加えた。最終容量 $10.4 \mathrm{~m} \ell$ のち から一部をとって比色定量をおこなった。

\section{III. 結 果}

1.PAF の血管透過性方進作用に及ぼす LPC の影響

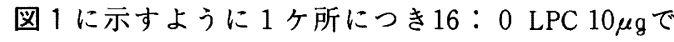
は，血管障害に基づく色素漏出は認められなかったが, $50 \mu \mathrm{g}$ では約 $100 \mu \mathrm{g}$ の色素が，また $500 \mu \mathrm{g} て ゙ は 150 \mu \mathrm{g}$ 以上 の色素漏出が認められ, 濃度依存的にその程度を増強し

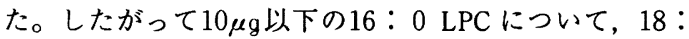
0 PAF 30ng の血管透過性立進作用の抑制効果を調べ た。

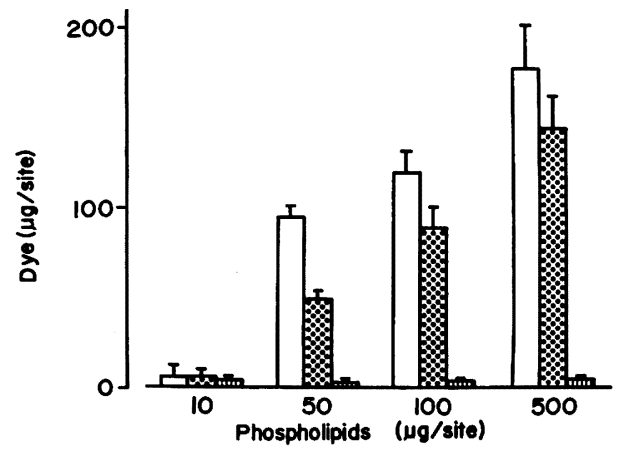

図 1 LPC 及び SPH 単独投与時の血管透過性に 及ぼす影響

16:0 LPC

$\therefore: \because::$ : $18: 1$ LPC

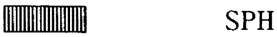

縦軸は漏出色素量を表わし，横軸は投与した $16 ： 0$ LPC, 18：1 LPC および SPH それぞれの濃度を表わす。 16：0 LPC と 18：1 LPC は0.1\% BSA 含有タイロード 液に溶解しSPH は乳濁色, 賏濁液として用いた。

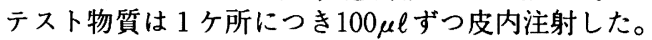

その結果，図 2 に見られるように 1 ケ所につき 5 及び $10 \mu \mathrm{g}$ では対応のない $\mathrm{t}$ 検定をとってみると有意に色素 漏出を抑制したが， $2.5 \mu \mathrm{g}$ では有意な抑制を示さなかっ た。

一方 $18 ： 1$ LPC の場合は, 図 2 にみられるように, 2.5,

$5,10 \mu \mathrm{g}$ の濃度いずれでも抑制効果を示さなかった。

16：0および18：1 LPC，それぞれの血管障害によ る色素漏出量を比較してみると，1 ケ所につき $10 \mu \mathrm{g}$ は相方統計的に有意の差は認められなかった（図 1)

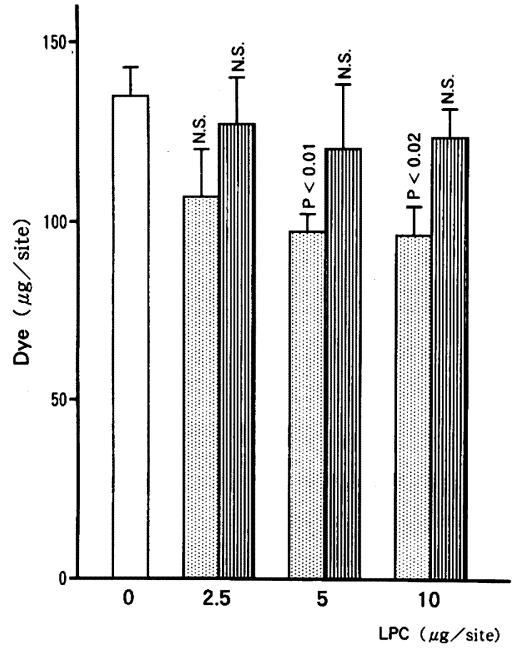

図 2 PAF による血管透過性充進作用に及ぼす LPC の影響

18：0 PAF 30ng/site 単独投与時

上記 PAF 及び各濃度の $16 ： 0 \mathrm{LPC}$ 混注時 上記 PAF 及び各濃度の18：1 LPC 混注時

2. ヒスタミン, ブラジキニン, セロトニンによる血管 透過性六進作用に及ほす LPC の影響

血管透過性立進作用を有するヒスタミン, ブラジキニ ン，セロトニンをそれぞれ 1 ケ所に付き $10 ４ ＼mathrm{~ ， ~}$ $0.3 \mu \mathrm{g}$ 用い $16 ： 0$ LPC の抑制作用を検討したが, 図 3 に見られるように色素漏出が増強されるという結果で あり，PAFのみがLPCによって抑制された。

関連して DPPC 1 ケ所につき $10 \mu \mathrm{g}$ を用いPAF に対す る抑制効果を調べたが抑制しなかった。DPPC 2.5，5， $10 \mu \mathrm{g}$ と $\mathrm{PAF}$ の色素漏出を抑制することはなかった。 (図省略)

3.PAF の血管透過性艺進作用に対する SPH の影響

SPH 単独では LPC と異なり, 色素漏出促進作用は大 量の場合でも認められなかった。(図 1 )

この SPH の, PAF による血管透過性亢進作用に対す る抑制効果を検討した結果は図 4 に示したように認めら れなかった。

さらに $0.1 \%$ のPH の $1 \%$ \% ライトン X -100 溶液を 作成し，用に望み $0.1 \%$ BSA 含有タイロード液で希釈し てもちいた。それらの希釈液は無色透明で白濁は見られ なかった。0.01\%のトライトンX-100のタイロード溶 液単独で血管よりの色素漏出を確かめた結果, $0.1 \%$ で は著明な色素漏出を認め, $0.01 \%$ では認められなかった。 (図省略) 図 4 に示したように0.01\%トライトンXー 100 含有タイロード溶液の SPH 1, $10 \mu \mathrm{g}$ 相方とも PAF の色素漏出を抑制できなかった。 


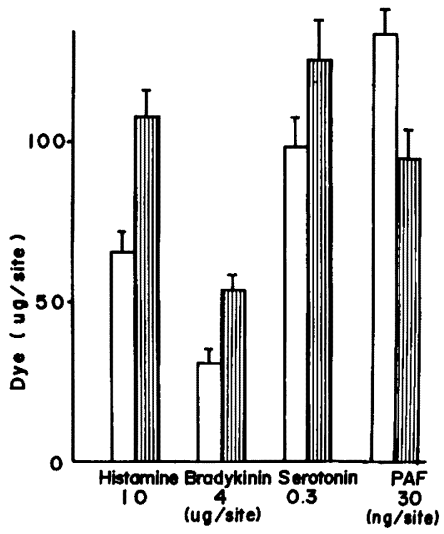

図316：0 LPCのヒスタミン, ブラジキニン, セロトニン及び PAF 各アゴニストによる 血管透過性立進作用に及ぼす抑制効果

各アゴニストの単独投与時の漏出色素量

上記アゴニストと $16 ： 0 \mathrm{LPC} 10 \mu \mathrm{g}$ を混注した 時の漏出色素量

垂㨁棒はスタンダードエラーを表わす。

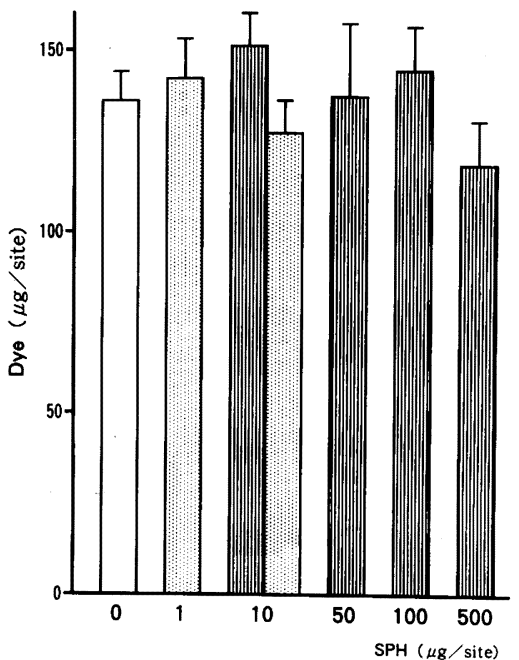

図 4 18：0 PAF による血管透過性立進作用に 及ぼす SPH の影響

18：0 PAF 30ng/site 単独投与時

m.

上記 PAF 及び SPH (タイロード懸濁液) 混注時 上記 PAF 及び SPH $(0.01 \%$ ア トイン X 100 含有タイロード液溶解）混注時

縦軸は漏出色素量を表わし，横軸は1ケ所あたりの SPHの濃度を表わした。

4. CV-3988 および $\mathrm{L}-652 ， 731$ の PAF による血管 透過性元進作用に及ぼす影響

PAF 受容体拮抗物質である CV-3988, ${ }^{31)}$ L-652, $731^{32)}$ による PAF の血管透過性圥進作用に対する抑制 効果を調べた。CV-3988に関しては，林らの詳細な報
告 $^{33)}$ があり同様の結果を得た。すなわち CV-3988 は, 16：0 PAF や18：0 PAFによって誘発されるラット皮 虚における血管透過性圥進作用を濃度依存的に抑制し た。(図省略) 一方 L-652，731についての報告はなく 検討を加えた。

18：0 PAF 80ng と L-652, 731 1, 2, 4, $8 \mu \mathrm{g}$ をれぞれ混注した結果は図 5 の通りで, それぞ れの濃度について有意な抑制効果が認められた。

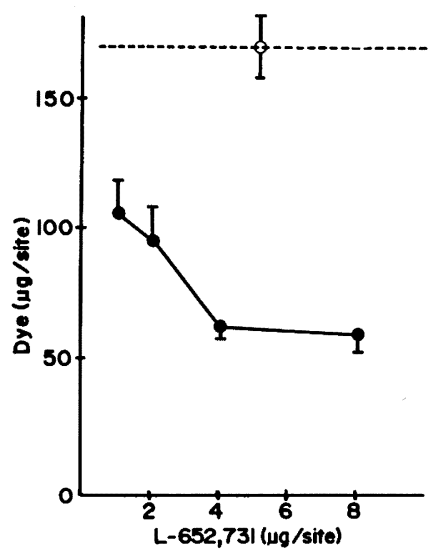

図 5 血管透過性元進作用に及ぼす L-652, 731 の濃度依存的抑制効果

18：0 PAF 80ng/site 単独投与時

上記 PAF 及び $\mathrm{L}-652 ， 731$ 混注時

スタンダードエラーにて表示してある。

\section{N. 考察}

正常組織内のPAF の存在は酵素的に示唆されてお $\eta^{34)}$ 事実安田らによってラット正常子宮内に見出され た。22) 1987年, 中山らによってラット（発情期）子宮内 にはPAF の血小板凝集作用を阻害する物質が存在し, それらがアシル LPC, アルキル LPC, スフィンコミエ リンの分子種の混合物と同定された。 はウサギの血小板凝集に対しての阻害効果であった。

一般にラット血小板はPAFにより凝集しない35.36.37) とされているので, 上記ラットの LPC, SPH の阻害作 用は血小板凝集には関与せず, その他の PAF の生理活 性と係わることが推定される。したがって今回私は PAF によるラットの血管透過性亢進作用に対する LPC, SPH の抑制効果を調べた。子宮では妊娠成立に伴って 血管の透過性が六進するがPAF はこれに関与している という。 ${ }^{38)}$ 今回実験に用いた LPC は血小板凝集能抑制作 用の強い $16 ： 0$ 及び18：1 LPCであり,一方 PAF は 16 
：0よりも血管透過性六進作用の弱い18：0 PAFで あった。その結果16：0 LPCによる抑制効果はわずか の範囲であったが，このことは生体内における PAF の 血管透過性立進作用を内在性の LPC は抑制する可能性 を示唆している。

元来 LPC は細胞融解作用があり, 細胞融合を誘発す るとも言われているが, 色素漏出については16：0 LPC 1 ケ所につき $10 \mu \mathrm{g}\left(2 \times 10^{-4} \mathrm{M}\right)$. 以下では認めら

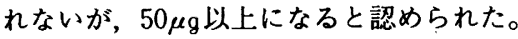

PAFによる透過性元進作用はヒスタミン，七ロトニ ンの受容体拮抗物質たとえばサイプロヘプタジン等の投 与によって抑制されないと報告されており，年）今回の実 験でもヒスタミン，ブラジキニン，七ロトニンによる血 管透過性六進作用は LPCにより抑制されなかった。従っ て LPC のPAF に対する抑制作用はかなり特異性がある と思われる。

人の血管内皮細胞はヒスタミン，トロンビンやブラジ キニン等の刺激にてプロスタサイクリンやPAFを産生 すると報告されており ${ }^{14,17,41,42)}$ 血栓形成や，血管の恒 常維持にそれらの相互作用がどの様に係わっているのか 興味深い。PAF 受容体競合的拮抗物質であるカズレ, ン, L-652, 731 は血槳漏出量を血管透過性の示標と して用いた Hwang $ら^{43)}$ の実験によれば, PAF，ヒス夕 ミンあるいはブラジキニンによるラットの皮唐の血管透 過性六進作用を有意に抑制したという。しかし今回私の 実験ではLPC はヒスタミンによる色素漏出を抑制しな かった。その差は彼らが用いたヒスタミン, ブラジキニ ンの量は我々の約100 1000倍であり，その為に PAF が 誘導された結果かもしれない。あるいは $\mathrm{L}-652,731$ はPAF 受容体以外にヒスタミン,ブラジキニンによる 血管透過性六進作用の経路をブロックするのかも知れな い。

一方今回の研究では SPH は色素漏出に関して拮抗的

1 ) Benveniste, J., Henson, P. M. and Cochrane, C. G.: Leukocyte-dependent histamine release from rabbit platelets. The role of IgE, basophils, and a plateletactivating factor. J. Exp. Med., 136, 1356-1377, 1972.

2 ) Hanahan, D. J., Demopoulos, C. A., Liehr, J. and Pinckard, R. N.: Identification of platelet activating factor isolated from rabbit basophils as acetyl glyceryl ether phosphorylcholine. J. Biol. Chem., 255,
に働かなかった。その一因として今回の実験で用いた牛 脳 SPH は, ラット子宮 SPH と分子種レベルで異なって いる事が考えられるが，詳細は今後，検討する予定であ る。一方 LPC でも $16 ： 0$ と $18 ： 1$ とでその作用が異なっ ていたが, 脂肪酸の炭素数や不飽和結合の有無がその作 用発現にどの様に関与しているのか, 今後検討を加えて ゆきたい。又病的状態だけでなく正常状態維持に係わる PAF 及びその抑制物質の相互抑制機構等, 解明の待た れるところであり研究を進めてゆきたいと思う。

\section{V. 結語}

PAF によるウサギ洗浄血小板の凝集を阻害する 2 種 類のリン脂質（LPC，SPH）が正常ラット子宮に見出さ れたが,これらリン脂質が, PAF の血管透過性六進作 用を抑制するか否かを調べた。

1 ケ所につき $5,10 \mu \mathrm{g}$ の $16: 0$ LPC は30ng の18：0 PAF による色素漏出を有意に抑制したが， $50 \mu \mathrm{g}$ 以上の 単独使用では LPC 自体が色素漏出を生じさせた。一方, $18 ： 1 \mathrm{LPC}$, 及びSPH (牛脳) は, どの濃度でも抑制効 果を示さなかった。

1 ケ所につきヒスタミン $10 \mu \mathrm{g}$, ブラジキニン $4 \mu \mathrm{g}$, セロトニン $0.3 \mu \mathrm{g}$ による色素漏出を $16 ： 0 \mathrm{LPC}$ は抑制 しなかった。

PAF のレセプターアンタゴニストである $\mathrm{L}-652$, 731 は CV-3988 と同様にPAF による色素漏出を濃度 依存的に著明に抑制した。

稿を終えるに臨み，貴重な合成資料を御恵与戴きまし た東京医科歯科大学教養部化学教室村松敏夫教授, 終始 愁切なる御指導と御校閲を賜わりました恩師第一内科学 教室安永幸二郎教授ならびに医化学教室齋藤國彦教授に 深甚の謝意を捧げます。

5514-5516, 1980.

3) MeManus, L. M., Hanahan, D. J. and Pinckard, R. N.: Human Platelet stimulation by acetyl glyceryl ether phosphorylcholine. J. Clin. Invest., 67, 903906, 1981.

4 ) Shaw, J. O., Pinckard, R. N., Ferrigni, K. S., MeManus, L. M. and Hanahan, D. J.: Activating of human neutrophils with 1-0-hexadecyl/octdecyl-2-acetyl-sn-glyceryl-3-phosphorylcholine (platelet acti- 
vating factor). J. Immunol., 127, 1250-1255, 1981.

5 ) Findlay, S. R., Lichtenstein, L. M., Hanahan, D. J. and Pinckard, R. N.: Contraction of guinea pig ileal smooth muscle by acetyl glyceryl ether phosphoryIcholine. Am. J. Physiol., 241, C130-C133, 1981.

6 ) Blank, M. L., Snyder, F., Byers, L. W., Brooks, B. and Muirhead, E. E.: Antihypertensive activity of an alkyl ether analog of phosphatidylcholine. Biochem. Biophys. Res. Commun., 90, 1194-1200, 1979.

7 ) Humphrey, D. M., McManus, L. M., Satouchi, K., Hanahan, D. J. and Pinckard, R. N.: Vasoactive properties of acetyl glyceryl ether phosphorylcholine and analogues. Lab. Invest., 46, 422-427, 1982.

8 ) Stimler, N. P., Bloor, C. M., Hugli, T. E., Wykle, R. L., McCall, C. E. and O'Flaherty, J. T.: Anaphylactic actions of platelet-activating factor. Am. J. Pathol., 105, 64-69, 1981.

9 ) Lotner, G. Z., Lynch, J. M., Betz, S. J. and Henson P. M.: Human neutrophil-derived platelet activating factor. J. Immunol., 124, 676-684, 1980.

10) Betz, S. J. and Henson, P. M.: Production and release of platelet-activating factor (PAF): dissociation from degranulation and superoxide production in the human neutrophil. J. Immunuol., 125, 1756$1763,1980$.

11) Jouvin-Marche, E., Ninio, E., Beaurain, G., Tence, M., Niaudet, P. and Benveniste, J.: Biosynthesis of PAF-acether (Platelet-activating factor). VII. Precursors of PAF-acether and acetyl-transferase activity in human leukocytes. J. Immunuol., 133, 892-898, 1984.

12) Ludwig, J. C., Hoppens, C. L., McManus, L. M., Mott, G. E. and Pinckard, R. N.: Moduiation of plateletactivating factor (PAF) synthesis and release from human polymorphonuclear leukocytes (PMN): Role of extracellular albumin. Arch. Biochem. Biophys., 241, 337-347, 1985.

13) Oda, M., Satouchi, K., Yasunaga, K. and Saito, K.: Molecular species of platelet-activating factor generated by human neutrophils challenged with ionophore A23187. J. Immunuol., 134, 1090-1093, 1985.

14) Prescott, S. M., Zimmerman, G. A. and MeIntyre, T. M.: Human endothelial cells in culture produce platelet-activating factor (1-alkyl-2-acetyl-sn- glycero-3-phosphocholine) when stimulated with thrombin. Proc. Natl. Acad. Sci., USA, 81, $3534-$ 3538, 1984.

15) Zimmerman, G. A., McIntyre, T. M. and Prescott, S. M.: Thrombin stimulates the adherence of neutrophils to endothelial cells in vitro. J. Clin. Invest., 76, 2235-2246, 1985.

16) MeIntyre, T. M., Zimmerman, G. A. and Prescott, S. M.: Leukotrienes $\mathrm{C}_{4}$. and $\mathrm{D}_{4}$. stimulate human endothelial cells to synthesize platelet-activating factor and bind neutrophils. Proc. Natl. Acad. Sci. USA, 83, 2204-2208, 1986.

17) MeIntyre, T. M., Zimmerman, G. A., Satoh, K. and Prescott, S. M.: Cultured endothelial cells synthesize both pratelet-activating factor and prostacyclin in response to histamine, bradykinin, and adenosine triphosphate. J. Clin. Invest., 76, 271-280, 1985.

18) Oda, M., Satouchi, K., Yasunaga, K. and Saito, K: Polymorphonuclear leukocyte-platelet interactions: Acetylglyceryl ether phosphocholine-induced platelet activation under stimulation with chemotactic peptide. J. Biochem., 100, 1117-1123, 1986.

19) Cox, C. P., Wardlow, M. L., Jorgensen, R. and Farr, R. S.: The presence of platelet-activating factor (PAF) in normal human mixed saliva. J. Immunuol., 127, 46-50, 1981.

20) Sanchez-Crespo, M., Inarrea, P., Alvarez, V., Alonoso, F., Egide, J. and Hernando, L.: Presence in normal human urine of a hypotensive and platelet-activating phospholipid. Am. J. Physiol., 244, F706F711, 1983.

21) Caramelo, C., Fernandez-Gallardo, S., Marin-Cao, D., Inarrea, P., Santos, J. C., Lopez-Novoa, J. M. and Crespo, M. S.: Presence of platelet-activating factor in blood from humans and experimental animals: Its abscence in anephric individuals. Biochem. Biophys. Res. Commun., 120, 789-796, 1984.

22) Yasuda, K., Satouchi, K. and Saito, K.: Platelet-activating factor in normal rat uterus. Biochem. Biophys. Res. Commun., 138, 1231-1236, 1986.

23) Sugatani, J., Fujimura, K., Miwa, M., Mizuno, T., Sameshima, Y. and Saito, K.: Occurrence of platelet-activating factor (PAF) in normal rat stomach and alteration of PAF level by water immersion stress. FASEB J., 3, 65-70, 1989. 
24) Tokumura, A., Kamiyasu, K., Takauchi, K. and Tsukatani, H.: Evidence for existece of various homologues and analogues of platelet activating factor in a lipid extract of bovine brain. Biochem. Biophys. Res. Commun., 145, 415-425, 1987.

25) Nakayama, R., Yasuda, K. and Saito, K.: Existence of endogenous inhibitors of platelet-activating factor (PAF) with PAF in rat uterus. J. Biol. Chem., 262, 13174-13179, 1987.

26) Saito, K. and Hanahan D. J.: A study of the purification and properties of the phospholipase A of Crotalus adamanteus Venom. Biochemistry, 521-532, 1962.

27) Bligh, E. G. and Dyer, W. J.: A rapid method of total lipid extraction and purification. Can. J. Biochem. Physiol., 37, 911-919, 1959.

28) Oh-ishi, S., Tanaka, K., Katori, M., Han, Y. N., Kato, $\mathbf{H}$ and Iwanaga, S.: Further studies on biological activities of new peptide fragments derived from high molecular weight kininogen: an enhancement of the vascular permeability increase of the fragments by prostaglandin $\mathrm{E}_{2}$. Life Sci., 20, 695$700,1977$.

29) Oh-ishi, S., Hayashi, M. and Yamaki, K.: Inflammatory effects of acetylglycerylether phosphorylchoine: vascular permeability increase and induction of pleurisy in rats. Prostaglandins Leukot. Med., 22, 21-33, 1986.

30) Katayama, S., Shionoya, H. and Oh-take, S.: A new simple method for extraction of extravasated dye in the skin. Jap. J. Pharmacol., 25, 103, 1975.

31) Terashita, Z., Tsushima, S., Yoshioka, Y., Nomura H., Inada Y. and Nishikawa K.: CV-3988-a specific antagonist of platelet activating factor (PAF). Life Sciences, 32, 1975-1982, 1983.

32) Doebber, T. W., WU, M. S. and Biftu, T.: Plateletactivating factor (PAF) mediation of rat anaphylactic responses to soluble immune complexes. Studies with PAF receptor antagonist $\mathrm{L}-652,731$. J. Immunuol. 136, 4659-4668 1986.

33) Hyashi, M., Kimura, J., Oh-ishi, S., Tsushima, S. and Nomura, H.: Characterization of the activity of a platelet activating factor antagonist, $\mathrm{CV}-3988$. J. J. Pharmacol., 44, 127-134, 1987.

34) Renooij, W. and Snyder, F.: Biosynthesis of 1- alkyl-2-acetyl-sn-glycero-3-phospocholine (platelet activating factor and a hypotensive lipid) by cholinephosphotransferase in various rat tissues. Biochim. Biophys. Acta., 663, 545-556, 1981.

35) Namm, D. H., Tadepalli, A. S. and High, J. A.: Species specificity of the platelet responses to $1-0-$ alkyl-2-acetyl-sn-glycero-3-phosphocholine.

Thromb. Res., 25, 341-350, 1982.

36) Cargill, D. I., Cohen, D. S., Van Valen, R. G., Klimek, J. J. and Levin, R. P.: Aggregation, release and desensitization induced in platelets from five species by platelet activating factor (PAF). Thromb. Haemost., 49, 204-207, 1983.

37) Terashita, Z., Imura, Y. and Nishikawa, K.: Inhibition by $\mathrm{CV}-3988$ of the binding of $\left[{ }^{3} \mathrm{H}\right]$-platelet activating factor (PAF) to the platelet. Chem. Pharm., 34, 1491-1495, 1985.

38) Billah, M. M. and Johnston, J. M.: Identification of phospholipid platelet-activating factor $(1-0$-alkyl2-acetyl-sn-glycero-3-phosphocholine) in human amniotic fluid and urine. Biochem. Biophys. Res. Commun., 113, 51-58, 1983.

39) Poole, A. R., Howell, J. I. and Lucy, J. A.: Lysolecithin and cell fusion. Nature, 227, 810-817, 1970.

40) Hwang, S. B., Li, C. L., Lam, M. H. and Shen, T. Y.: Characterization of cutaneous vascular permeability induced by platelet-activating factor in guinea pigs and rats and its inhibition by platelet-activating factor receptor antagonist. Lab. Invest., 52, 617$630,1985$.

41) Weksler, B. B., Ley, C. W. and Jaffe, E. A.: Stimulation of endothelial cell prostacyclin production by thrombin, trypsin, and the ionophore A23187. J. Clin Invest., 62, 923-930, 1978.

42) Baenziger, N. L, Force, L. E. and Becherer, P. R.: Histamine stimulates prostacyclin synthesis in cultured human umbilical vein endothelial cells. Biochem. Biophys. Res. Commun., 92, 1435-1440, 1980.

43) Hwang, S. B., Lam, M. H., Biftu, T. Beattie, T. R. and Shen, T. Y.: Trans-2, 5'Bis- $(3,4,5-$ trimethoxyphenyl) tetrahydrofuran. J. Biol. Chem., 260, 15639-15645. 1985. 


\title{
(欧 文 抄 録)
}

\section{The Effect of Antagonists to PAF Activity, Vascular Permeability Increase.}

\author{
Mariko Yamamoto \\ The first Department of Internal Medicine, Kansai Medical University, Moriguchi, Osaka 570, Japan \\ (Director: Professor Kojiro Yasunaga, M. D.) \\ Department of Medical Chemistry, Kansai Medical University, Moriguchi, Osaka 570, Japan \\ (Director: Professor Kunihiko Saito. M. D.)
}

It has been reported that lysophosphatidylcholine (LPC) and sphingomyelin (SPH) from rat uterus inhibited the $\mathrm{PAF}$-induced aggregation of washed rabbit platelets. However, rat platelets are not responsive to PAF.

In this paper, I studied the inhibitory effects of LPC and SPH on PAF-induced vascular permeability of the rat.

Intradermal injection of PAF increased the infiltration of Brilliant blue $6 \mathrm{~B}$ into the skin in a dose-dependent manner. The vascular permeability induced by 30ng 18: 0 PAF was reduced significantly by 16: 0 LPC at concentrations of 5 and 10 ug. However, at concentrations greater than $50 \mathrm{ug} / \mathrm{site}$, it enhanced the permeability, probably due to its cytolytic activity. Vascular permeability was also inhibited significantly by L-652, 731 and CV-3988, which are PAF antagonists. On the other hand, 18: 1 LPC and SPH had no effect at all concentrations tested.

16: 0 LPC did not inhibit the increse of vascular permeability induced by histamine (10 ug/ site), bradykinin ( $4 \mathrm{ug} / \mathrm{site})$ or serotonin ( $0.3 \mathrm{ug} / \mathrm{site})$.

The physiological significance of endogeneous LPC is discussed. 